\title{
Binding of Sulfonyl-Containing Arylalkylamines at Human 5-HT 6 Serotonin Receptors
}

Donald Sikazwe, ${ }^{1}$ Mikhail L. Bondarev, ${ }^{1}$ Matgorzata Dukat,${ }^{1}$ Jagadeesh B. Rangisetty, ${ }^{1}$ Bryan L. Roth ${ }^{2}$ and Richard A. Glennon ${ }^{1}$

Results of elemental analysis. 
Calculated \%
C
$\mathrm{H}$
H
C
$\mathrm{H}$
$\mathrm{N}$

\begin{tabular}{|c|c|c|c|c|c|c|}
\hline $6 a$ & 56.38 & 6.21 & 8.22 & 56.10 & 6.17 & 8.03 \\
\hline $6 b$ & 54.37 & 5.93 & 8.45 & 54.06 & 5.99 & 8.38 \\
\hline $6 c$ & 53.09 & 5.02 & 7.83 & 53.12 & 5.05 & 8.00 \\
\hline $6 d$ & 51.51 & 5.09 & 7.07 & 51.57 & 5.25 & 6.96 \\
\hline 7 & 53.41 & 6.08 & 8.90 & 53.39 & 6.19 & 8.85 \\
\hline $9 \mathbf{a}$ & 52.44 & 5.88 & 11.46 & 52.38 & 5.65 & 11.31 \\
\hline $9 \mathrm{~b}$ & 50.45 & 6.08 & 11.03 & 50.26 & 5.94 & 10.74 \\
\hline 12 & 53.63 & 5.30 & 7.36 & 53.92 & 5.46 & 7.77 \\
\hline 13 & 49.66 & 4.44 & 7.47 & 49.61 & 4.62 & 7.57 \\
\hline 14 & 50.61 & 4.60 & 9.84 & 50.61 & 4.57 & 9.83 \\
\hline 15 & 52.45 & 4.95 & 7.65 & 52.66 & 5.08 & 7.42 \\
\hline 16 & 56.46 & 5.41 & 4.70 & 56.25 & 5.28 & 4.59 \\
\hline 17 & 63.26 & 6.07 & 5.27 & 63.32 & 6.12 & 5.27 \\
\hline 18 & 52.45 & 4.95 & 7.65 & 52.25 & 4.96 & 7.78 \\
\hline $20 a$ & 56.71 & 5.65 & 8.25 & 56.94 & 5.72 & 8.20 \\
\hline $20 \mathrm{~b}$ & 54.54 & 5.86 & 7.95 & 54.28 & 5.61 & 7.94 \\
\hline 20c & 56.71 & 5.65 & 8.25 & 56.52 & 5.49 & 8.08 \\
\hline
\end{tabular}


